\title{
Implementation of E-Government as a Public Service Innovation in Indonesia
}

\author{
I. Farida, A. Lestari \\ University of Bandar Lampung, \\ 29, Pagar Alam, Labuhan Ratu, Lampung, Indonesia, 35142
}

\begin{abstract}
E-Government implementation is the use of technology, information, and communication to realize more efficient and effective government practices in the process of implementing public services in order to facilitate public access to information and create principles of accountability, transparency and good public participation in the Indonesian government. This study aims to explain the implementation of E-Government in Indonesia which encourages the development of information and data systems and is adapted to existing bureaucratic processes. The method used in this research is qualitative research methods. The results showed that public service innovation organized by the government of the Republic of Indonesia was able to create relationships between elements in a country online, not inline, so that efficiency and speed in public services was not only a symbol but a reality.
\end{abstract}

Keywords: implementation, e-government, innovation, public service, Indonesia

Conflicts of interest: The authors declared no conflicts of interest.

Article history:

The article was submitted on 29.11.2020. The article was accepted on 10.12.2020.

For citation:

Farida I., Lestari A.I. Implementation of E-Government as a Public Service Innovation in Indonesia. RUDN Journal of Public Administration. 2021; 8(1): 72-79. DOI: 10.22363/23128313-2021-8-1-72-79

\section{Внедрение электронного правительства как инновации государственной службы в Индонезии}

\author{
И. Фарида, А. Лестари \\ Университет Бандар-Лампунг, \\ 35142, Индонезия, Лампунг, Лабухан Рату, Пагар Алам, 29
}

Аннотация. Внедрение электронного правительства - это пример использования информационных и коммуникационных технологий для реализации более эффективных и действенных правительственных практик в процессе реализации государственных услуг с целью облегчения доступа общественности к информации и создания принципов подотчет-

(C) Farida I., Lestari A., 2021

cc) (7) This work is licensed under a Creative Commons Attribution 4.0 International License https://creativecommons.org/licenses/by/4.0/ 
ности, прозрачности и надлежащего участия общественности в деятельности правительства Индонезии. Это исследование направлено на объяснение особенностей внедрения электронного правительства в Индонезии, которое способствует развитию информационных систем и баз данных и адаптировано к существующим бюрократическим процессам. Данное исследование опирается на использование качественных методов. Полученные исследовательские результаты показали, что инновации в сфере общественных услуг, организованные правительством Республики Индонезия, смогли сформировать отношения между участниками коммуникации в стране в режиме онлайн способствовав реальному росту эффективности и скорости предоставления государственных услуг.

Ключевые слова: внедрение инноваций, электронное правительство, инновации, государственная служба, Индонезия

\section{Заявление о конфликте интересов:}

Авторы заявляют об отсутствии конфликта интересов.

\section{История статьи:}

Статья поступила в редакцию: 29.11.2020. Статья принята к публикации: 10.12.2020

\section{Для цитирования:}

Фарида И., Лестари А. Внедрение электронного правительства как инновации государственной службы в Индонезии // Вестник Российского университета дружбы народов. Серия: Государственное и муниципальное управление. 2021. Т. 8. № 1. С. 72-79. DOI: 10.22363/23128313-2021-8-1-72-79

\section{Introduction}

E-Government implementation in Indonesia is not only understood as a form of transferring the work of government institutions from manual labor systems to computerized or online-based systems. However, philosophically, the implementation of E-Government according to Aritonang [1] is a form of bureaucratic work that dynamically experiences distortions in the external environment of the organization or there are demands that require change. So clearly the implementation of E-Government is part of the change in the mindset of the bureaucracy, which has been considered slow and has many openings for mistakes to occur. Implementation of E-Government requires the development of information and data systems and alignment with existing bureaucratic processes, so that by utilizing information communication technology will support the bureaucratic process optimally. Implementation of E-Government requires planning and design of a mature model by looking at the following needs: a) compatibility between the vision, mission and objectives of E-Government with the vision, mission and objectives of government; b) there is a synchronization between the data information system and the bureaucratic process; c) appropriate strategies; d) have a structured and gradual process; and e) the existence of adequate human and financial support [2].

Based on this explanation, it can be seen that the implementation of E-Government is the use of technology, information and communication to realize more efficient and effective governance practices in the process of implementing public services, to make it more affordable and to expand public access to information, so as to create the principle of accountability. transparency and high public participation in government. In the implementation of E-Government in 
Indonesia, the services provided by government institutions can minimize bureaucratic work and ultimately services that are efficient, effective, economical and just for the community at large [3].

By looking at the benefits that will be generated from the implementation of E-Government in Indonesia, it can be said that implementation is a must in order to create better public services [4]. In Indonesia, the development of E-Government has been determined by the government through Presidential Instruction of the Republic of Indonesia No.3 of 2003 concerning National Policy and Strategy. According to the Instruction, E-Government Development is an effort to develop electronic-based government administration in improving the quality of public services effectively and efficiently [3; 4].

In preparing the strategic plan for E-Government development, the government of the Republic of Indonesia has a role as a policy provider regarding the E-Government development strategy by providing directions on the preparation of E-Government strategic plans to all government agencies in accordance with the context of each of these agencies. E-Government or electronic-based government is increasingly playing an important role for all decision makers [4]. Traditional government which is identical to paper-based administration has begun to be removed and changed [5]. Thus the implementation of E-Government in every government institution from central to regional will provide services without the intervention of public institution employees and a long queue system just to get a simple service, the use of technology that makes it easier for the public to access information can reduce corruption by increasing corruption. transparency and accountability of public institutions, it is possible for the public to be actively involved in decision making or policies by the government, which can improve the productivity and efficiency of the bureaucracy and increase economic growth in Indonesia.

\section{Research Methods}

In this study, the method used is qualitative research methods through literature study. Qualitative research is research that produces descriptive information and data contained in the text under study [6;7]. The data used comes from secondary data relating to the implementation of E-Government in Indonesia. The research data collection method is carried out by the method of documentation that refers or collects documented materials [8; 9]. Meanwhile, the data collection tool used is documentation study, namely study by studying data in the form of books, research reports, journals, seminar papers, writings of experts, and the laws of the Republic of Indonesia relating to research material. The research data were analyzed using content analysis. Content analysis is carried out on all secondary data collected, but content analysis is mainly carried out on documents in the form of books, laws and regulations and relevant journals.

\section{The Concept of Innovation in Improving the Quality of Public Services}

Innovation is something that introduces new ideas, new goods, new systems, new approaches or even renewable ways of service so as to provide more benefits 
for the wearer. In particular, innovation in the public sector can be defined as the application of new ideas in implementation, characterized by a significant change in steps, so that the implementation process will have a significant impact on organizational changes and the organizational structure of the public sector [10].

Innovation in public services has a distinctive characteristic, namely its intangible, because service and organizational innovation is not based solely on unseen products but on changes in the relationship of the perpetrator, namely between service providers and service receivers or relationships between various parts of the organization or partners an organization [2]. The process of forming an innovation can be driven by various situations, generally innovation in public services can be created in the form of initiatives such as:

a. Partnerships in public service delivery, both between government and government $(\mathrm{G} 2 \mathrm{G})$, government with the business sector $(\mathrm{G} 2 \mathrm{~B})$, Government with society (G2C), and government with employees (G2E);

b. Use of information technology for communication in public services;

c. Procurement or establishment of service institutions that clearly increase the effectiveness of services (health, education, law or public safety);

d. Increasing the enrichment of the role of the internal government system that previously existed in society [11].

Innovations in service methods are new changes in interacting with customers or new ways of providing services [12]. Innovations in system interaction include new or updated ways of interacting between actors in the governance framework. We can see the typology of public sector innovation based on Figure 1 below:

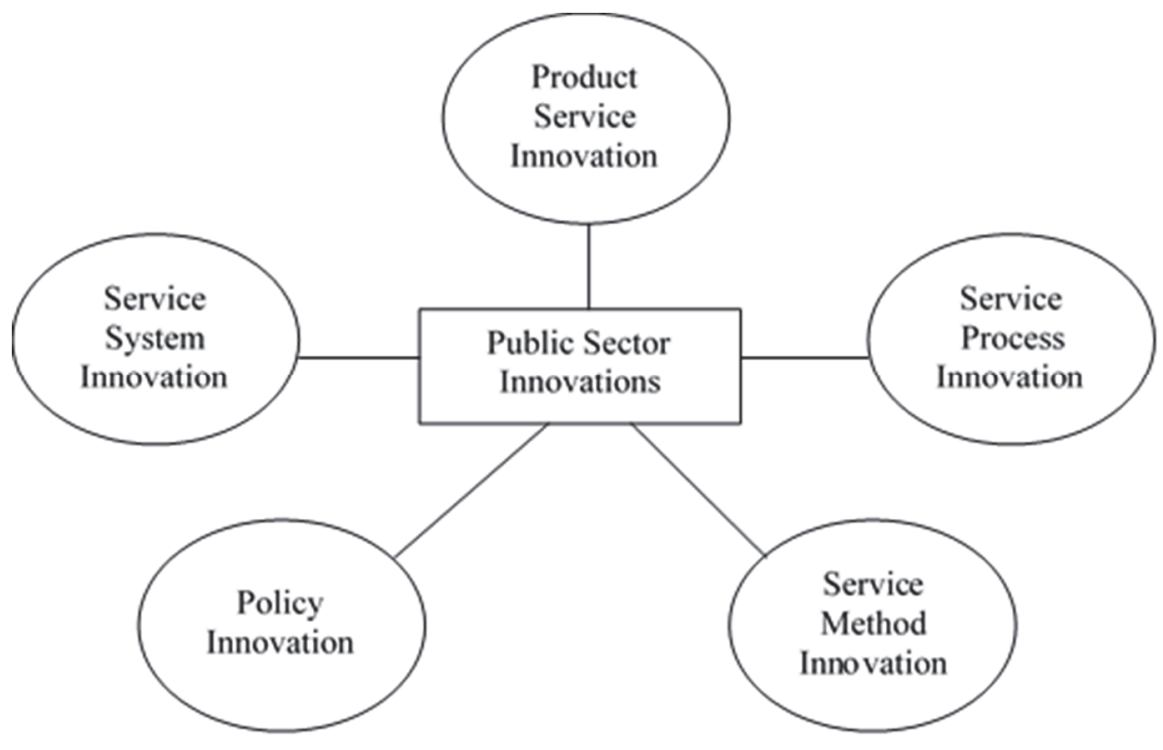

Figure 1. Typology of Public Sector Innovation

Source: Gonçalo [13].

Innovation in the public sector is one way to overcome the impasse of public organizations. The characteristics of the public sector system are known to be rigid, rigid and tend to be status quo, so they need to be disbursed through the 
transmission of a culture of innovation. Based on the opinion of Gonçalo [5] as a public sector organization can adopt innovation through the following stages:

a. Initiation or pioneering.

This stage consists of the general setting and matching phases, where initiation is the initial stage in the introduction of situations and problems faced by the organization. The agenda setting stage is carried out as a process of identifying and prioritizing needs and problems. This stage often takes a very long time, where at this stage, a performance gap or performance gap is usually identified. The gap that appears is what will trigger the innovation search process in the organization. Next is the matching phase, which is the stage where problems have been identified and adjustments need to be made to the innovation to be adopted. This stage ensures the feasibility of the innovation to be applied to the organization's performance.

b. Implementation or application.

In the initiation stage, a decision has been made to seek and accept innovations that are considered to be able to solve organizational problems, then at the implementation stage there are redefinition, clarification and routineization phases. In the redefinition phase, all the innovations that are adopted begin to lose their foreign character. Innovation has gone through a re-invention process, so that it is closer to accommodating the needs of the organization. In this phase, both innovation and organization have redefined each other and have undergone a process of change to suit each other. In general, there are at least changes to the organizational structure and patterns of leadership approaches in the organization.

\section{Implementation of E-Government as a Public Service Innovation in Indonesia}

The implementation of public services is a state effort to fulfill the basic needs and civil rights of every citizen of goods, services and administrative services [14]. An objective assessment of the services provided to public service providers shows that they are still not effective, efficient, economical and do not even see aspects of social justice so that they have a dimensional impact on the bureaucracy with the emergence of public service practices that deviate from the government [15].

Changes from the impact of globalization, which resulted in the acceleration of change dynamically delivered a message to every modern organization to be responsive to technological advances and the rapid flow of information that can be captured by the wider community [16]. Because this change is the best solution for organizations, especially public sector organizations, in meeting the aspects of transparency, accountability and public participation. Integration of government administration systems through an integrated online information network. This needs to be developed, especially in the provision of services through accessibility which includes the availability of data and information in agencies that can be analyzed and utilized quickly, accurately and safely [17].

E-Government is an internet-based application product which is realized based on the needs of the current internetization era. E-Government is managed 
by the government for online services that connect a relationship between government and government $(\mathrm{G} 2 \mathrm{G})$, government and business actors $(\mathrm{G} 2 \mathrm{~B})$, and government and civil society $(\mathrm{G} 2 \mathrm{C})$. The following is an illustration or description of the patterns and references to standardization of web-based public services in local governments [18]:

Implementation of E-Government in Indonesia which has been commonly implemented and regulated is the creation of a government website, where the website is a strategy in implementing the development of the E-Government concept systematically through realistic and measurable stages. The objectives of implementing E-Government in Indonesia in general are as follows:

a) Creating a better business environment;

b) Creating online consumers who are more effective and efficient in serving and receiving services;

c) Strengthen to be good governance and expand public participation;

d) Increase government productivity;

e) Improve the quality of life and public interest. [18; 19].

The implementation of good public services, depending on the condition of the bureaucracy in a country. The bureaucratic condition provides its own climate for the implementation of optimal public services. Efforts to make a good bureaucracy by prioritizing effective and efficient values can be answered with the concept of E-Government which is part of innovation in changing the mindset of the bureaucracy that has been rigid and convoluted. E-Government with a real concept and making bureaucratic flow easy is an indispensable innovation in the development of public services [14].

The E-Government approach cannot be developed in a bottom-up manner, this fact is that if it is carried out bottom-up, the more difficult it is to integrate the results to the top. This condition requires a leadership commitment (political will) to determine the policy direction of implementing e-Government. The right solution is to find the right leadership pattern for the application of the E-Government concept, so that it can be realized in a sustainable manner. The definition of political will mentioned provides the main concept developed by Indrajit [19] in the framework of planning and developing E-Government. Without a leadership political will, it is impossible for E-Government to be successfully implemented nationally, so that the political will is:

1. Support for political leadership has a sustainable commitment;

2. Availability of allocated funds that have been budgeted and are ready to be disbursed;

3. Agreement to carry out cross-sectoral coordination;

4. Intention to start compiling related regulations in support of initiatives for implementing E-Government;

5. Readiness of government resources to learn and change the way of working in accordance with the desired transformation; and

6. Efforts to make system improvements so that E-Government can take place in a sustainable and consistent manner [20].

The good application of E-Government in the regions needs to get great attention for the central government to harmonize and implement it nationally so 
that E-Government is not only understood by a handful of groups who want change, but that change must be formulated into the big agenda of this country in facing global challenges. currently. Based on the above opinion also, that EGovernment cannot be carried out or implemented bottom-up, but must be strengthened from above, considering that investment in the application of EGovernment will be very costly and require long stages to be implemented, then the key The success lies in the visionary leadership to commit to change through the application of E-Government as the basis for implementing public services that can create prosperity for the community at large. There are complex problems faced in the application of the E-Government system to improve governance. The main problem is resistance and indecision when facing new innovations to break old habits. Siagian [4] summarizes three major aspects of the problem in the application of the E-Government system, one of which is the cultural aspect which becomes a real problem, this can be seen from the resistance and rejection of the public and government against the E-Government system. This is an obstacle for the government of the Republic of Indonesia to innovate.

\section{Conclusion}

Based on this description, it can be concluded that in the implementation of E-Government as the basis for public service innovation organized by the government of the Republic of Indonesia, it aims to create relationships between elements in a country online, not inline. E-Government provides a signal for public sector organizations that have a priority in the public interest to provide services without bureaucratic intervention in creating services that are simple and highly valuable, efficient and effective. This condition is inseparable from realizing a good governance framework in reforming its services by changing service procedures and changing the mission and culture of the bureaucracy from a culture of controlling behavior to a culture of making it easier for citizens to obtain public services in Indonesia.

\section{REFERENCES}

[1] Aritonang D. The Impact of E-Government System on Public Service Quality in Indonesia. European Scientific Journal. 2017; 13 (35): 99-111. DOI: 10.19044/ esj.2017.v13n35p99

[2] Asmuni W. Opportunities and Challenges in Implementing E-governance in the Context of Regional Autonomy. Surabaya: Airlangga University; 2019.

[3] Dwiyanto A. Realizing Good Governance Through Public Services. Yogyakarta: Gadjah Mada University Press; 2018.

[4] Farida I., Setiawan R., Maryatmi A.S., Juwita M.N. The Implementation of E-Government in The Industrial Revolution Era 4.0 in Indonesia. International Journal of Progressive Sciences and Technologies. 2020; 22 (2): 340-346.

[5] Mansour F. The Collapse of Development Theory and Globalization. Yogyakarta: Insist Press, 2018.

[6] Setiawan R. Peranan Etika Aparatur Sipil Negara Dalam Pelayanan Publik Pada Dinas Kependudukan Dan Catatan Sipil (Disdukcapil) Kota Bandar Lampung. Jurnal e-JKPP. 2016; 2 (2): 46-57 (In Indon.).

[7] Thoha M. Bureaucracy of the Indonesian Government in the Reformation Era. Jakarta: Kencana Prenada Media Group; 2011. 
[8] Creswell J.W. Research Design: Qualitative, Quantitative and Mixed Approaches. Yogjakarta: PT Student Library; 2015.

[9] Mustafa D. Government Bureaucracy. Bandung: Alfabeta; 2017.

[10] Farida I., Setiawan R. Leadership in Cope With Prostitute in Social Department of Bandar Lampung. International Journal of Social Sciences And Development. 2018; 2 (1): 1-8. DOI: https://doi.org/10.24967/saburaiijssd.v2i1.325

[11] Moleong L. Qualitative Research Methodology. Bandung: Remaja Rosda Karya; 2013.

[12] Robbins S.P. Organization Theory: Structure, Design, and Application. Jakarta: Arcan; 2015.

[13] Gonçalo P.D. Fifteen Years of E-Government Research in Ibero-America: A Bibliometric Analysis. Journal Elsevier/ Government Information Quarterly. 2019; 36 (3): 400-411. DOI: $10.1016 /$ j.giq.2019.05.008

[14] Setiawan R., Abdurahman A., Pertiwi P.G., Saputri S. Reaksi Perekonomian Rusia Ditengah Pandemi Covid-19. 'Adalah. 2020; 4 (1). DOI: 10.15408/adalah.v4i1.17935

[15] Setiawan R. Partisipasi Publik Dalam Program Bantuan Listrik Pedesaan Masyarakat Kabupaten Mesuji. Jurnal e-JKPP. 2017; 3 (3): 82-92.

[16] Sanjaya P. Public Administration Theories and Applications of Good Governance. Bandung: Rafika Aditama; 2016.

[17] Sedarmayani Public Administration Reform, Bureaucracy Reform, and Future Leadership. Bandung: Refika Aditama; 2017.

[18] Setiawan R., Melinda E. Optimization of the Implementation of Village Government in Indonesia. RUDN Journal of Public Administration. 2020; 7 (4): 352-360.

[19] Wibawa S. State Administration of Contemporary Issues. Yogyakarta: Graha Ilmu; 2018.

[20] Widodo J. Building Performance-Based Bureaucracy. Malang: Bayumedia Publishing; 2019.

\section{Information about the authors:}

Ida Farida - Lecturer of the Department of Public Administration, University of Bandar Lampung (Indonesia) (ORCID ID: 0000-0002-7408-4214) (e-mail: ida.farida@ubl.ac.id).

Annisa Lestari - Lecturer of the Department of Public Administration, University of Bandar Lampung (Indonesia) (ORCID ID: 0000-0002-9598-5679) (e-mail: annisaikalestari313@gmail.com).

\section{Информация об авторах:}

Фарида Ида - преподаватель кафедры государственного управления Университета БандарЛампунг (Индонезия) (ORCID ID: 0000-0002-7408-4214) (e-mail: ida.farida@ubl.ac.id).

Лестари Анниса - преподаватель кафедры государственного управления Университета БандарЛампунг (Индонезия) (ORCID ID: 0000-0002-9598-5679) (e-mail: annisaikalestari313@gmail.com). 